\title{
Pengaruh Anti Oksidan Terhadap Kestabilan Sifat Fisis Bahan Polipaduan Polipropilena-Karet Alam: I. Studi Morfologi dan Sifat Mekanik
}

\author{
Mashuri, ${ }^{1, *}$ Ana Marini, ${ }^{1}$ dan Sudirman ${ }^{2}$ \\ ${ }^{1}$ Jurusan Fisika, FMIPA, Institut Teknologi Sepuluh Nopember, Kampus ITS Sukolilo, Surabaya 60111 \\ ${ }^{2}$ Laboratorium P3IB Batan, PUSPIPTEK Serpong, Tangerang, Banten
}

\section{Intisari}

\begin{abstract}
Telah dilakukan studi morfologi dan sifat mekanik pengaruh anti oksidan terhadap kestabilan sifat fisis bahan polipaduan polipropilena-karet alam yang mengalami penjemuran selama 12 minggu di alam terbuka. Untuk mengamati peran anti oksidan dalam menghambat terjadinya reaksi oksidasi pada polipaduan PP-KA(4:1) digunakan Irganok 1076 dengan konsenrasi 4\%, 6\%, 8\% dan 10\% vol. Polipaduan dibuat dengan metode blending pada temperatur $176 \circ \mathrm{C}$ dengan rotasi $30 \mathrm{rpm}$ selama 10 menit. Hasil penelitian menunjukkan Irganok 1076 sebagai bahan anti oksidan tidak berpengaruh terhadap tingkat kekompakan (misibilitas) polipaduan PP-KA dan masih termasuk jenis immiscible blends. Konsentrasi optimal irganok 1076 sebagai bahan anti oksidan yang berperan menghambat terjadinya reaksi oksidasi pada polipaduan PP-KA yang mengalami penjemuran selama 12 minggu di alam terbuka sebesar 6\% vol. Polipaduan PP-KA-Irganok 1076 6\% mengalami peningkatan YS sebesar $40 \%$, TS sebesar $56 \%$ dan elongation at break sebesar $21 \%$ dalam penjemuran selama 12 minggu. Secara morpologis kestabilan kekuatan tarik polipaduan PP-KA menjadi lebih baik dengan adanya irganok 1076 yang ditandai dengan tidak terbentuknya cacat garis dan cacat bidang pasca penjemuran selama 12 minggu.
\end{abstract}

KATA KUNCI: polipaduan, anti oksidan, blending

\section{PENDAHULUAN}

Bahan polipaduan merupakan perpaduan antara beberapa polimer yang mempunyai jenis dan sifat yang berbeda, serta sifatnya yang berbeda dengan sifat polimer penyusunnya [1]. Karena sifatnya yang dapat dikendalikan dengan cara memilih bahan polimer penyusun polipaduan dan parameter sintesis, maka membuat bahan polipaduan ini banyak dipilih dan dikembangkan sebagai bahan alternatif untuk berbagai keperluan seperti keperluan konstruksi dan rekayasa bahan serta isolator.

Bahan polipaduan terdiri dari bahan polimer sebagai matrik dan polimer dengan jenis yang berbeda sebagai pengisi, yang dicampurkan ke dalam matrik. Sifat akhir bahan polipaduan yang dihasilkan sangat bergantung pada karakteristik polimer pengisi, meliputi konsentrasi dan jenis, dan sifat ikatan adesi antar muka matrik-pengisi yang menentukan kompaktibilitas polipaduan serta tingkat penyebaran polimer pengisi dalam matrik. Sejauh ini telah dilakukan beberapa penelitian bahan polipaduan yang mengkaji sifat mekanik $[2,3,12]$, sifat kompaktibilitas polipaduan $[2,5,13]$, sifat termal [13].

Dalam penelitian yang mengkaji tingkat kekompakan (miscible) dari polipaduan telah dilakukan eksperimen pada polipaduan polikarbonat (PC)-akrilonitril butadiene stirena (ABS), polivinil klorida(PVC)-akrilonitril butadiene stirena (ABS), poliamida (PA)-akrilonitril butadiene stirena(ABS),

\footnotetext{
*E-MAIL: mash@physics.its.ac.id
}

polivinil klorida (PVC)-polietilena (PE). Hasil menunjukkan bahwa polipaduan PC-ABS, PA-ABS dan PVC-PE termasuk jenis polipaduan tak kompak (immiscible blends), sedangkan PVC-ABS termasuk polipaduan jenis kompak (miscible blends)[2]. Dalam penelitian yang mengkaji sifat tarik dari polipaduan telah dilakukan eksperimen pengukuran kebergantungan tegangan luluh, kekuatan tarik dan regangan patah serta modulus elastik pada konsentrasi bahan pengisi. Hasil tersebut menunjukkan bahwa polimer pengisi berperanan dalam menurunkan tegangan luluh, kekuatan tarik dan regangan patah tetapi meningkatkan modulus elastic[2, 3]. Sementara itu pada polipaduan jenis kompak (miscible blends) polimer pengisi lebih mampu meningkatkan kekuatan tarik dan regangan patah dibanding dengan polipaduan jenis tak kompak (immiscible blends), hal ini dikarenakan pada saat mendapatkan beban tarikan terjadi sobekan awal (craze) pada antar muka polimer matrik-pengisi pada polipaduan jenis tak kompak[2, 4].

Untuk meningkatkan sifat tarik dari bahan polipaduan, terdapat beberapa cara yang dapat dilakukan seperti menumbuhkan rantai ikat silang dengan agen ikat silang (crosslink agent), meningkatkan daya kekompakan matrik-pengisi dengan menambahkan bahan pengompak (compactibilizer), dan meningkatkan penyebaran polimer pengisi dengan menggunakan agen pendispersi fasa padat (SPD, solid phase dispersant)[5]. Pada penelitian pengaruh rantai ikat silang terhadap sifat kuat tarik polietilena (PE), rantai ikat silang dapat meningkatkan kekuatan tarik dan regangan patah serta temperatur leleh, hal ini disebabkan bentuk tiga dimensi rantai ikat silang lebih mampu mereduksi beban tarikan dari luar 


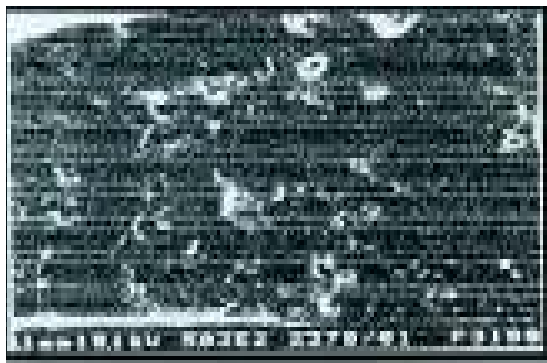

Gambar 1: Morfologi polipaduan PP-KA(20\% vol)

[13]. Ghaffar, et.al, 1981, telah melakukan penelitian perbaikan sifat mekanik dari polipaduan PE (polietilena) - PVC (polivinil klorida) dengan menggunakan cara mensinergikan bahan pengompak (compactibilizer) dan penumbuh rantai ikat silang (crosslink agent) dan hasilnya sifat kuat tarik polipaduan tersebut meningkat. Hal ini terjadi karena polimer matrik sebagai tempat pengumpulan tegangan mampu mereduksi tegangan serta adesi antar muka matrik-pengisi lebih dapat terbentuk dengan baik. Polipaduan PP (polipropilena) - KA (karet alam) termasuk jenis polipaduan tak kompak, tingkat sebaran KA sebagai pengisi masih kurang homogen dan gaya ikat permukaan kontak fasa matrik-pengisi kurang terbentuk dengan sempurna sehingga menimbulkan titik-titik lemah yang mendegradasikan sifat mekanik secara keseluruhan. Polipaduan PP-KA mempunyai sifat transparansi terhadap sinar dan mempunyai kemampuan mulur putus yang lebih baik. Salah satu aplikasinya digunakan dibidang teknologi pertanian, contohnya sebagai plastik penutup lahan ketika dilakukan penanaman lombok atau melon. Degradasi sifat mekanik bahan polipaduan saat diaplikasikan di lapangan disebabkan oleh serangan sinar ultra violet dan reaksi oksidasi dengan udara luar[7, 8], di samping itu sifat ketidakkompakan polimer matrik dengan polimer yang dipadukan juga merupakan potensi terjadinya degradasi sifat mekanik polipaduan dengan cepat terutama sifat kekuatan tarik.

Pada makalah ini dilaporkan hasil penelitian pengendalian kecepatan degradasi sifat mekanik bahan polipaduan PP-KA yang diakibatkan oleh serangan reaksi oksidasi, pengendalian yang dilakukan dengan menghambat terjadinya reaksi oksidasi. Upaya tersebut dilakukan dengan menambahkan bahan aditif antioksidan pada polipaduan PP-KA yaitu Irganok 1076[6, 7]. Perilaku sifat mekanik akhir yang dihasilkan dari proses sintesis suatu bahan polipaduan sangat bergantung pada karakteristik bahan polimer matrik, bahan polimer pengisi, keadaan antar muka matrik-pengisi, tingkat distribusi polimer pengisi dalam matrik, konsentrasi polimer pengisi (filler), proses pembuatan dan pemberian bahan aditif. Hal ini terutama pada bahan polipaduan jenis tak kompak (immiscible blends) seperti polipaduan PP-KA. Untuk mengkaji permasalahan tersebut pada makalah ini dititik beratkan hasil penelitian pengaruh konsentrasi KA sebagai fasa filler dan konsentrasi irganok 1076 sebagai antioksidan terhadap kestabilan sifat kekuatan tarik polipaduan PP-KA pasca mengalami perlakuan penjemuran dalam rentang waktu 12 minggu. Sebagai bahasan pendukung adanya kestabilan kekuatan tarik polipaduan, cacat yang terjadi dan sifat immiscible blends yang dimiliki polipaduan PP-KA dilaporkan hasil kajian secara morfologi.

\section{METODE PENELITIAN}

\section{A. Bahan}

1. Polipropilena berbentuk butiran bening dengan MFI 4 $\mathrm{gr} / 10$ minutes, temperatur leleh $176^{\circ} \mathrm{C}$, densitas 0,896 $\mathrm{gr} / \mathrm{cm}^{3}$, produksi PT Tri Polyta Indonesia Tbk, sebagai bahan matrik.

2. Karet Alam berbentuk lembaran dengan temperatur leleh $130^{\circ} \mathrm{C}$, densitas $0,792 \mathrm{gr} / \mathrm{cm}^{3}$ dari latex pohon karet Kalimantan, sebagai bahan pengisi (filler).

3. Irganok 1076 berbentuk serbuk putih dengan densitas $0,480 \mathrm{gr} / \mathrm{cm}^{3}$, sebagai bahan anti oksidan.

\section{B. Pembuatan dan Pengujian Bahan Polipaduan}

Sampel yang dibuat terdiri dari 2 (dua) macam yaitu pertama, polipaduan PP-KA tanpa anti oksidan dengan variasi KA, 5, 10, 15, 20 dan 25\% vol. dan kedua polipaduan PPKA (4:1) dengan anti oksidan yang divariasi $4 \%, 6 \%, 8 \%$ dan $10 \%$ vol. Komposisi masing-masing sampel ditimbang dengan neraca timbang digital merk Precisa 3000 D Swiss Quality kapasitas $3 \mathrm{~kg}$, kemudian dimasukkan ke dalam alat Rheologi $30 \mathrm{rpm}$ kapasitas 60 gr untuk mengalami proses blending pada temperatur $176^{\circ} \mathrm{C}$ dalam waktu 10 menit dengan rotasi blending $30 \mathrm{rpm}$ (proses ini dilakukan di Dinas Pengendalian Mutu Petrokimia-DPMP PT Pertamina Pulo Gadung). Tahap berikutnya hasil proses blending dimasukkan ke alat cetak tekan panas dengan pembebanan $500 \mathrm{~kg} / \mathrm{cm}^{2}$ selama 3 menit dan dipindahkan ke dalam alat cetak dingin dengan pembebanan hingga 16 ton dalam waktu 3 menit hingga diperoleh bentuk sampel berupa film tipis dengan ketebalan $1 \mathrm{~mm}$, menggunakan alat Hidrolik Press merk Toyoseiki Jepang. Untuk sampel kedua dilakukan penjemuran di alam terbuka dengan rentang waktu 1, 2, 4, 8 dan 12 minggu yang dilakukan di Surabaya, bulan Juni, Juli dan Agustus 2004. Selanjutnya semua sampel dilakukan pengujian kekuatan tarik dengan mengacu standar ASTM D 1822-L menggunakan alat uji tarik Strograph R1 Toyoseiki Jepang yang dilengkapi recorder U-228 merk Pantos Jepang, dan sampel dilakukan pengujian stukturmikro menggunakan alat Scanning Electron Microscope (SEM), type 515 Philips dan Coating Taab SEM S 500 Coating Unit. 

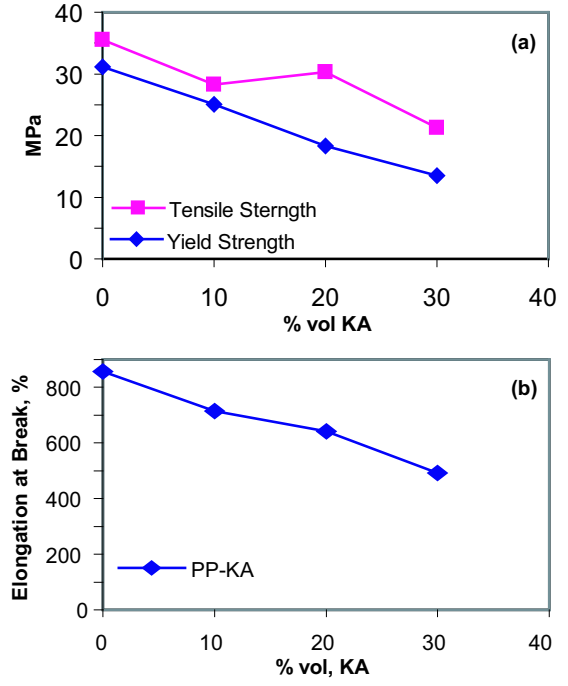

Gambar 2: (a) Tensile strength dan Yield strength polipaduan PP-KA dan (b) Elongation at break polipaduan PP-KA

\section{HASIL DAN PEMBAHASAN}

\section{A. Morfologi dan Kekuatan Tarik Polipaduan PP-KA}

Metode blending mempunyai kelebihan dalam distribusi fasa polimer filler lebih merata dalam fasa polimer matrik dibanding metode pembentukan polipaduan yang lain, hal ini dikarenakan teknik pencampuran yang dilakukan pada keadaan meleleh yang disertai putaran pencampurannya[1,2]. Polipaduan PP-KA yang dibuat dengan metode blending termasuk jenis immiscible blends dimana gaya kontak permukaan antara PP dan KA kurang bisa terbentuk secara sempurna terlihat pada fasa filler KA yang tidak kompaktibel dan kurang seragam ukuran fasa KA, seperti yang ditunjukkan morfologi polipaduan PP-KA pada Gambar 1. Distribusi KA kurang merata dan homogen maka secara bulk menyebabkan potensi kelemahan secara mekanik dari polipaduan, hal ini sesuai dengan hasil yang dilaporkan Valdir Mano, et.al[9].

Sifat kekuatan tarik polipaduan PP-KA ditentukan oleh salah satunya faktor konsentrasi KA sebagai fasa filler selain sifat fisis polimer matrik dan pengisi. Semakin besar konsentrasi KA hingga 30\% vol menyebabkan penurunan nilai Yield Strength sekitar 56\% dan Tensile Strength sekitar $40 \%$ polipaduan PP-KA dibanding polipropilena seperti yang ditunjukkan hasil uji tarik pada Gambar 2(a). Karakteristik mekanik polipaduan ini disebabkan oleh KA mempunyai kekuatan luluh (YS, yield strength) dan kekuatan tarik (TS, tensile strength) rendah dibanding PP dan semakin besar konsentrasi KA akan memperbanyak luasan kontak fasa KA - PP dimana daerah permukaan ini mempunyai sifat yang lemah secara mekanik karena sifat immiscible (kompatibel yang tidak sempurna). Pada konsentrasi $20 \%$ vol KA penurunan TS polipaduan hanya sekitar $14 \%$, hal ini dimungkinkan karena pada konsentrasi ini penyebaran fasa KA lebih merata dan ukuran fasanya lebih kecil dibanding nilai konsentrasi yang lain.

Elongation at break (kemampuan mulur putus) merupakan indikasi sifat suatu bahan dalam menahan beban tarikan dari luar hingga putus. Kemampuan mulur putus polipaduan PPKA semakin menurun sebesar $48 \%$ dengan meningkatnya konsentrasi fasa KA hingga $30 \%$ vol seperti yang ditunjukkan Gambar 2(b). Hipotesis awal secara teoritis perpaduan PP dan KA menyebabkan peningkatan kemampuan mulur putus polipaduan, penurunan yang tejadi disini memperlihatkan kurang signifikannya peran KA yang bersifat lebih kenyal (elastis) dibanding PP dalam sistem polipaduan. Faktor penting yang menyebabkan fenomena ini adalah kurang kompatibel dari PP-KA sehingga gaya ikatan kontak (adesi) pada permukaan PP-KA yang tidak terbentuk secara sempurna sehingga secara bulk melemahkan kemampuan bahan dalam menahan beban tarikan dari luar atau sifat plastisitas polipaduan menjadi berkurang.

\section{B. Pengaruh Penambahan Irganok 1076 Terhadap Morfologi dan Kekuatan Tarik Polipaduan PP-KA Pascapenjemuran Di Alam Terbuka}

Bahan PP termasuk jenis polimer termoplastik bersifat reversible, titik leleh tinggi, densitas rendah, trasparan terhadap cahaya, tahan terhadap air yang tinggi, tahan terhadap bahan kimia, kemampuan mulur putus relatif rendah, tidak tahan terhadap serangan pereaksi oksidasi terutama hidrokarbon dan klorinasi. Bahan KA mempunyai kemampuan luluh (YS), kekuatan tarik (TS) rendah dan kemampuan mulur putus tinggi serta bersifat lebih mampu mulur ketika mengalami pemanasan dengan sedikit belerang (vulkanisasi).

Salah satu aplikasi PP adalah pada bidang pertanian lombok, ketika mendapatkan penyinaran matahari (di alam terbuka) akan mudah mengalami degradasi mekanik yang disebabkan oleh putusnya rantai-rantai polimernya karena proses oksidasi. Polipaduan PP-KA diharapkan memperbaiki keelastisitasan bahan dalam bentuk polipaduan dengan sedikit mengurangi transparansinya. Serangan destruktif oleh oksidasi dapat diminimalisasi dengan menambahkan bahan anti oksidan pada polipaduan[8,9]. Salah satu bahan anti oksidan adalah Irganok 1076.

Peran irganok 1076 sebagai anti oksidan pada sifat kekuatan tarik polipaduan PP-KA yang mengalami perlakuan penjemuran di alam terbuka dengan rentang waktu $0,1,2,4,8$ dan 12 minggu dapat dilihat pada nilai TS, YS dan elongation at break pada Gambar 3. Pada hipotesis awal diharapkan irganok 1076 sebagai antioksidan akan dapat berfungsi dengan baik sehingga serangan destruktif dari sinar matahari tidak langsung pada rantai-rantai polimer PP dan KA. Pada konsentrasi irganok 1076 4\% dan 10\% vol yang ditambahkan pada polipaduan PP-KA, setelah mengalami penjemuran selama 12 minggu memperlihatkan kecenderungan menurunkan nilai TS, YS dan elongation at break hingga minggu ke 8 serta pada minggu ke 12 polipaduan bersifat getas dengan ditunjukkan polipaduan tidak mempunyai YS dan elongation at 

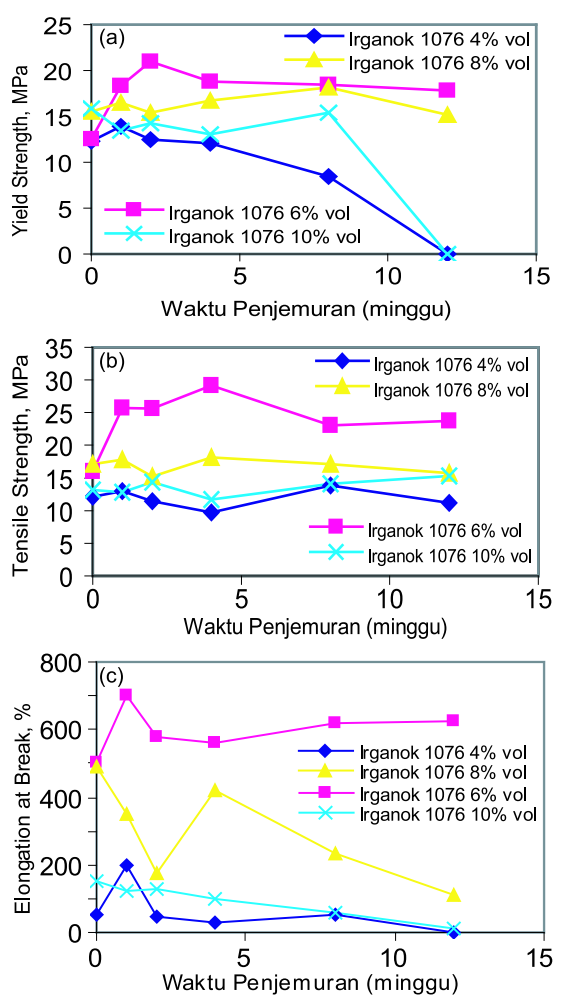

Gambar 3: (a)Yield strength polipaduan PP-KA Irganok 1076, (b)Tensile strength polipaduan PP-KA-Irganok 1076, dan (c). Elongation at break polipaduan PP-KA-Irganok 1076

break. Fenomena ini disebabkan pada konsentrasi 4\% irganok 1076, mulai minggu ke 8 keberadaannya mulai habis yang diakibatkan oleh faktor termal[11] sehingga peran penghambat oksidasi tidak maksimal dan sifat imkompatibel polipaduan lebih berperan dalam menentukan sifat kekuatan tarik bahan. Untuk nilai konsentrasi 10\% irganok 1076, justru melewati batasan optimal dan menimbulkan banyak radikal bebas yang memicu terjadinya degradasi gaya ikat kontak permukaan fasa matrik dan filler.

Optimalisasi peran penghambat oksidasi ditunjukkan irganok 1076 pada konsentrasi 6\% dimana nilai TS, YS dan elongation at break polipaduan mengalami peningkatan dan menunjukkan kestabilan sifat kekuatan tarik dari polipaduan PP-KA. Fenomena mekanik ini digambarkan dengan tidak terjadinya penurunan yang drastis atau signifikan hingga penjemuran selama 12 minggu.

Degradasi kestabilan sifat kekuatan tarik polipaduan PPKA yang merupakan salah satu faktor penyebabnya adalah terjadinya oksidasi dengan lingkungan. Upaya meminimalkan kelemahan mekanik tersebut dilakukan dengan menghambat proses reaksi oksidasi yang dilakukan dengan menambahkan bahan antioksidan. Morfologi degradasi kekuatan tarik dan peran irganok 1076 sebagai penghambat oksidasi pada polipaduan PP-KA ditunjukkan Gambar 4. Polipaduan PP-KA tanpa anti oksidan setelah mengalami penjemuran selama 8
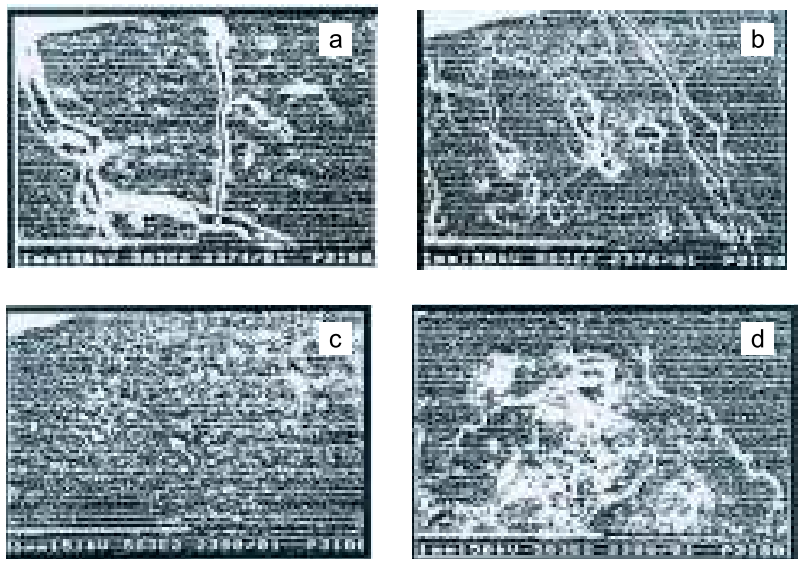

Gambar 4: (a) Morfologi PP-KA tanpa irganok penjemuran 8 minggu, (b) Morfologi PP-KA tanpa irganok penjemuran 12 minggu, (c) Morfologi PP-KA dengan 6\% irganok 1076 penjemuran 8 minggu, dan (d) Morfologi PP-KA dengan 6\% irganok 1076 penjemuran 8 minggu

dan 12 minggu ditunjukkan Gambar 4(a) dan (b) memperlihatkan adanya cacat garis yang dominan terjadi diawali pada permukaan kontak fasa PP dan KA serta cacat garis semakin diikuti terbentuknya cacat bidang pada minggu ke 12 , dimana keadaan ini tidak ditemui pada keadaan awal PP-KA tanpa mengalami penjemuran (Gambar 1). Cacat-cacat tersebut dimungkinkan karena terputusnya rantai-rantai PP dan gaya ikat permukaan kontak PP-KA. Hal ini salah satu penyebabnya adalah terjadinya reaksi oksidasi dengan lingkungan sehingga sifat kekuatan tarik polipaduan PP-KA cepat mengalami degradasi mekanik.

Peran irganok 1076 sebagai penghambat reaksi oksidasi pada polipaduan PP-KA yang optimal pada konsentrasi $6 \%$ vol. Peran tersebut sesuai dengan morfologi yang ditunjukkan Gambar 4(c) dan (d), yaitu tidak munculnya cacatcacat garis (8 minggu penjemuran) dan cacat garis dan bidang (12 minggu penjemuran). Fenomena inilah yang mendukung adanya keterhambatan proses reaksi oksidasi dengan lingkungan berlangsung dengan baik yang dilakukan irganok 1076 sehingga karakteristik kekuatan tarik polipaduan PP-KA lebih stabil dalam jangka waktu pemakaian hingga minggu ke 12.

\section{SIMPULAN}

1. Irganok 1076 sebagai bahan anti oksidan tidak berpengaruh terhadap tingkat kekompakan polipaduan PP-KA dan masih termasuk jenis immiscible blends.

2. Konsentrasi optimal irganok 1076 sebagai bahan anti oksidan yang berperan menghambat terjadinya reaksi oksidasi pada polipaduan PP-KA yang mengalami penjemuran selama 12 minggu di alam terbuka sebesar $6 \%$ vol. 
3. Polipaduan PP-KA-Irganok 1076 6\% mengalami peningkatan YS sebesar 40\%, TS sebesar 56\% dan elongation at break sebesar $21 \%$ dalam penjemuran selama 12 minggu.

4. Secara morpologis kestabilan kekuatan tarik polipaduan
PP-KA menjadi lebih baik dengan adanya irganok 1076 yang ditandai dengan tidak terbentuknya cacat garis dan cacat bidang pasca penjemuran selama 12 minggu.
[1] Callister, Materials Science and Engineering an Introduction, John Wiley \& Sons, New York, 1985.

[2] Pujiono dan Mashuri, Pengaruh Penambahan Polietilene, Polipropilena dan Polistirena Terhadap Sifat Termal dan Mekanik ABS dalam Bentuk Polipaduan, Presentasi Ilmiah di BATAN, Serpong, 2000.

[3] Meri Suhartini, Marga Utama, M. Sumarti, S. Susilowati, T. Puspitasari, D. Listina dan Marsongko, Studi Sifat fisik, Mekanik dan Termal Terhadap Campuran Kopolimer Karet Alam Stiren Dan Polietilena (LDPE), Penelitian dan Pengembangan Aplikasi Isotop, 1999.

[4] Supawan Tantayanon and Sukunya Juikham, Enhanced Toughening of Poly(propylene) with Reclaimed-Tire Rubber, Journal of Applied Polymer Science, vol. 91, pp. 510-515, 2004.

[5] E. Kroeze, G. ten Brinke and G. Hadziioannou, Compatibilization of Blends of Low Density Polyethylene and poly(vinyl chloride) by Segmented EB (SAN-block-EB)n Block Copolymers, Polymer, Vol. 38, No. 2, 1997.

[6] Dziezak, J.D, Antioxidant, the Ultimate Answer Oxidation, 3th ed. John Wiley \& Sons, Inc, New York, 1982.

[7] Christopher, M.H dan Ho, C.T, Natural Antioxidant, AOCS, Ohio, 1985
[8] Rabek, J.F, Photodegradtion of Polymer, Springer Verlag, New York, 1996.

[9] Valdir Mano, Maria Elisa Scarpelli Ribeiro e Silva, Niccoletta Barbani, Paolo Giusti, Blends Composed of Poly (" -isopropylacrylamide) and and Ethylene/Vinyl Alcohol Copolimer: Thermal and Morphologies Studies, Journal of Applied Polymer Science, vol. 91, pp. 501-505, 2004.

[10] Scott G, Development in Polymer Stabilization, Applied Science Publisher, London, 1979.

[11] Chengzhi Chuai, Kristoffer Almdal, Jorgen Lyngaae Jorgensen, Thermal Behavior and Properties of Polystyrene/Poly(methyl methacrylate) Blends, Journal of Applied Polymer Science, vol. 91, pp. 609-620, 2004.

[12] Mashuri, dan M. Z. Asrory, Pengarung Konsentrasi Bahan Penumbug Ikat silang pada sifat mekanik dan termal bahan polipaduan PE-ABS, Laporan Penlitian Dana Due-like ITS, 2001.

[13] Infrawan, Mashuri, dan Sudirman, Pengaruh iradiasi sinar gamma terhadap sifat mekanik dan fisis polipaduan PE-ABS, Majalah Sain dan Materi, vol. 2, 2001. 